\title{
Type section of the Triassic Bódvalenke Limestone Formation (Rudabánya Hills, NE Hungary) - the northwesternmost occurrence of a Neotethyan deep water facies
}

\author{
Sándor Kovács† \\ Geological, Geophysical and Space Science \\ Research Group of the Hungarian Academy of Sciences, Budapest
}

\begin{abstract}
The geologic key section at the northwestern margin of the village of Bódvalenke represents the stratotype of the Triassic Bódvalenke Limestone Formation and can be considered as the type section of the Bódva Unit of the Rudabánya Hills. The age of the exposed part of the formation in the type section ranges from the Late Anisian (Gondolella constricta cornuta partial range zone) to the early Late Carnian (Gondolella polygnathiformis interval zone). Its typical variety consists of purplish red to pinkish, strongly chertified, thinly-bedded micritic limestone, with frequent intercalations of mmthick purplish red shale layers and whitish-gray coquina beds. These beds are made up of tiny shells of Posydonia-like juvenile bivalves, often showing gradation. This deep water facies represents the transition between Hallstatt Limestone and red radiolarite. This facies type occurs from Oman via southern Turkey throughout the western ophiolite belt of the Hellenides-Dinarides until the Zagorje region in NW Croatia. Its northernmost, displaced occurrence is known in the Rudabánya Hills, NE Hungary, from where the type section is described and illustrated herein.
\end{abstract}

Key words: Triassic, deep water sedimentation, conodonts, Rudabánya Hills, paleogeography

\section{Foreword}

The manuscript of this paper was one of the unfinished or partly finished ones of Sándor Kovács. The problem of the so-called Bódvalenke-type limestone and its paleogeographic connections and significance was his favorite research area during his last years. His never-ending interest in deep-water limestone units, their stratigraphy and their paleogeography accompanied him all along his scientific career. The key section in Bódvalenke was his favorite "child". As a mark of respect to his memory, CEG is publishing his work on this famous locality without major modifications. The final editorial work on the manuscript was made by Szilvia Kövér.

Address: $\quad$ S. Kovács: H-1117 Budapest, Pázmány Péter sétány 1/c, Hungary

Received: January 3, 2011; accepted: January 25, 2011 


\section{Geologic-geographic setting}

The Bódvalenke geologic key section, shown in detail on Plate 1, can be found at the northwestern border of the village, just below the road curve (Fig. 1). Its GPS coordinates are N 48 $32^{\prime} 43.98^{\prime \prime}$, E $20^{\circ} 48^{\prime} 10.24 "$. The exposure, as one of the small isolated outcrops occurring NE of the main body of the Rudabánya Hills (Fig. 2), represents the type section of the Bódvalenke Limestone Formation and can be considered as the type section of the Bódva Unit (Grill et al. 1984; Kovács et al. 1989; Less 2000; Dosztály et al. 2002).

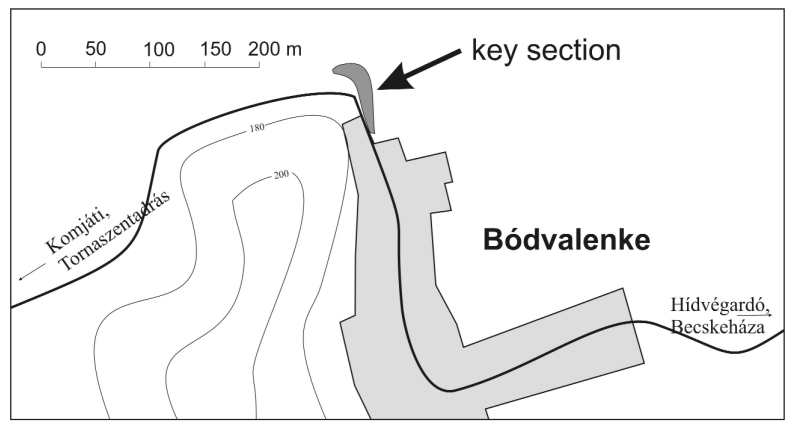

Fig. 1

Locality map of the Bódvalenke key section

\section{Research history}

The vicinity of the exposure and its continuation to the SW was first shown on a sketch map by Balogh (1950), as "Ladinian cherty limestone group", together with the metamorphosed Triassic outcrops slightly to the E, between Hidvégardó and Tornaszentjakab (the latter having been assigned to the "Torna Series" by Less 1981). The outcrop itself, strongly overgrown by vegetation, was unknown to Kálmán Balogh, and was discovered in the course of the geologic mapping of the Aggtelek and Rudabánya Hills by Less (1981), who distinguished the nonmetamorphosed, deep-water sequences of the Rudabánya Hills as the "Bódva Series". The conodont biostratigraphy and microfacies analysis of the section was published by Kovács (1986), and a guidebook within the framework of the Key Section Program by Kovács and Less (1987). As previously only a very concise English description of the section was available (Kovács and Less 1987 and in Dosztály et al. 2002), a more detailed one illustrated with color photos is presented herein.

\section{Stratigraphic sequence of the section}

The section, with practically vertical dipping, exposes an approximately $85 \mathrm{~m}$ thick succession ranging in age from Late Anisian to Early Norian (Fig. 3, Plate 1). Of this the first $45 \mathrm{~m}$ (exposed in the wall below the road, ranging in age up to early Late Carnian) includes the type section of the Bódvalenke Limestone Formation, shown on Plate 1. 

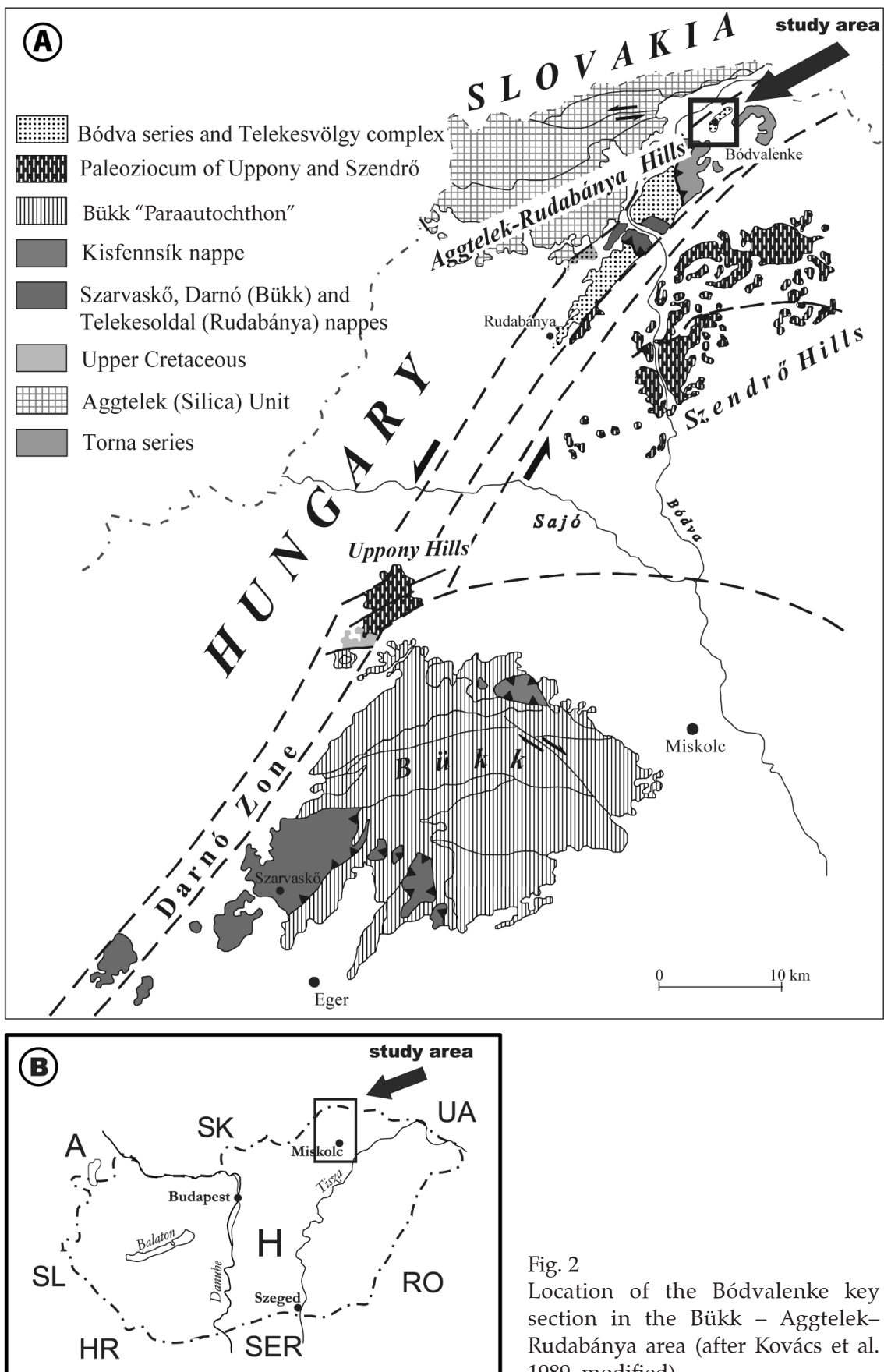

Fig. 2

Location of the Bódvalenke key section in the Bükk - AggtelekRudabánya area (after Kovács et al. 1989, modified) 
124 S. Kovács

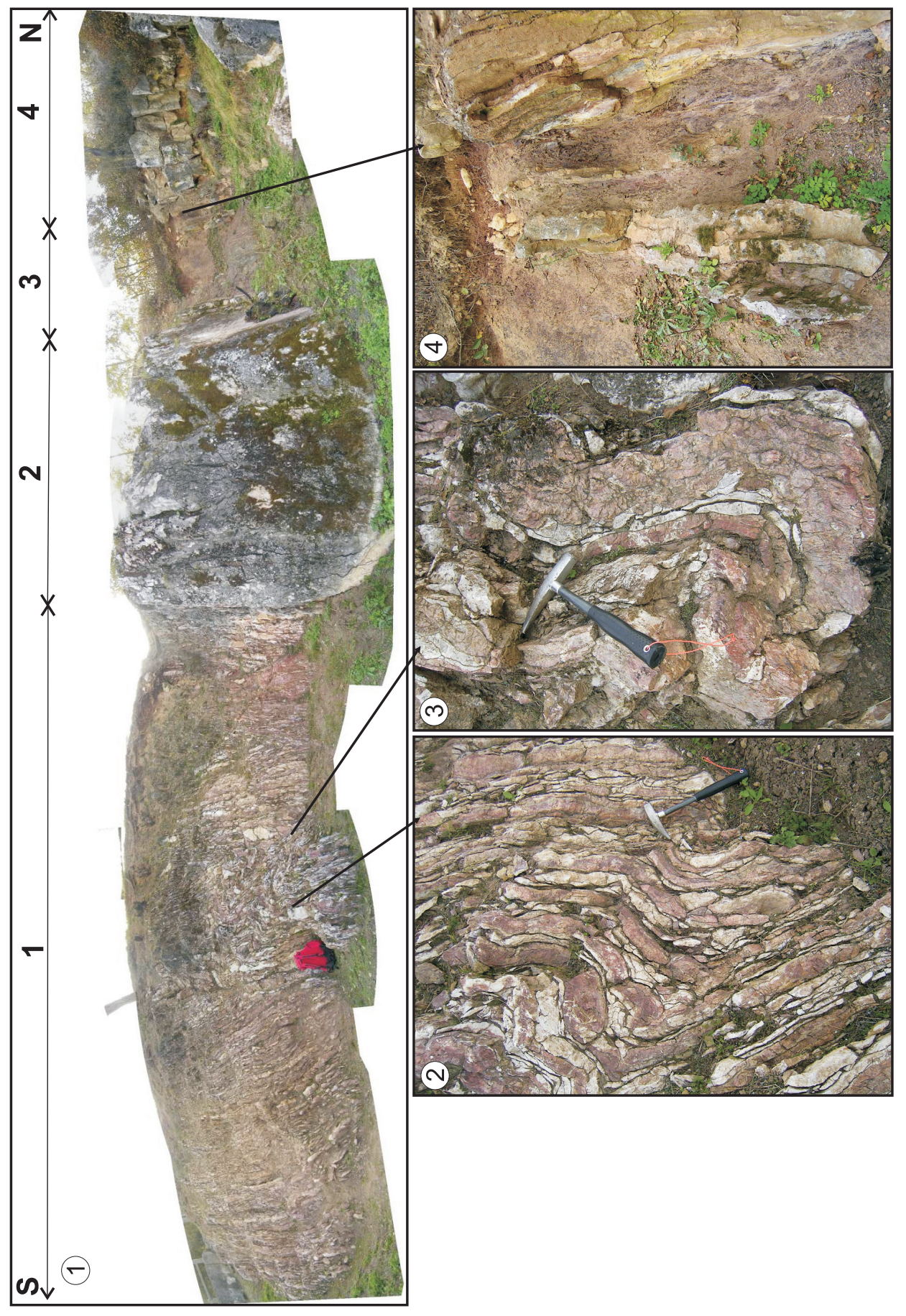

Central European Geology 53, 2010 
The contact with the underlying Steinalm Limestone Formation of carbonate ramp facies is not exposed, as the preceding $30 \mathrm{~m}$ interval toward the village is built into the wall of the road and is covered by concrete. However, the whitishcolored Steinalm Limestone is exposed in a cliff a few square meters large further to the $\mathrm{S}$, in the direction of the village, containing light brownish or pinkishcolored micritic limestone dykes, with conodonts indicating an age not younger than Middle Anisian (Pelsonian) (Gondolella bulgarica; cf. Kovács 1986). It provides an upper age limit for the break-up and drowning of the Steinalm carbonate ramp. On the other hand, the borehole Bódvalenke-2, drilled nearby, is a continuous succession from ramp facies to pelagic carbonates (Fig. 4); however, at the transition the Bódvarákó Fm., an anoxic basinal facies of a few meters thickness occurs.

At the beginning of the exposed and cleaned part of the sequence a flight of stairs has been established, on which the base of the section can be reached by walking downward. The preceding $10 \mathrm{~m}$ of the succession, still shown on the lowermost part of the columns by Kovács (1986) and Kovács and Less (1987), was later covered by concrete for road-mechanical reasons, but windows were left at the base of the wall, in which parts of the beds are still visible; they belong to interval 1 in the description below.

In the exposed and cleaned part of the section, shown on Fig. 3 and Plate 1, the following groups of beds are visible:

1. Alternation of thin-bedded $(<10 \mathrm{~cm})$ purplish red to pink, micritic limestone and partly thicker $(=10 \mathrm{~cm})$ beds of whitish gray to light gray, coarser crystalline "filament" limestone (coquinas consisting of masses of shells of Posydonia-like juvenile pelecypods), with red chert beds and lenses, and with usually mm-thick (max. 0.5-2 cm) purplish red shale intercalations (Plate 1/2-3). Thickness in the present state of the exposure: approximately $21.5 \mathrm{~m}$. This interval/group of beds represents the typical development of the formation. Between 11.5-14.3 m a characteristic slump horizon with distorted bedding is visible. Near to the upper end of the interval, red chert beds become predominant (Plate 1/3), showing a transition into almost pure red radiolarite.

$\leftarrow$ Plate 1

1. Panoramic view of the Bódvalenke Limestone Formation part (Upper Anisian to lower Upper Carnian) of the Bódvalenke key section

2 and 3. Typical development of the Bódvalenke Limestone Formation in the frontal part of the key section: alternation of thin $(<\mathrm{cm})$ beds of purplish-red to pink, micritic limestone and red chert with thicker (exceeding $10 \mathrm{~cm}$ ) beds of whitish-gray pelecypod coquina beds, with usually $\mathrm{mm}$ thick purplish-red shale intercalations

4. Lower (?) - Middle Carnian purplish-red, partly grayish-green shale horizon approximately $5 \mathrm{~m}$ thick, with purplish-red, micritic limestone olistoliths (pelagic equivalent of the "Raibl siliciclastic event") 
a
( $355^{\circ}$
(1) (2) (3)
$129^{\circ} \mid 270^{\circ}$
(4)
$90^{\circ} \mid 229^{\circ} \quad 49^{\circ}$

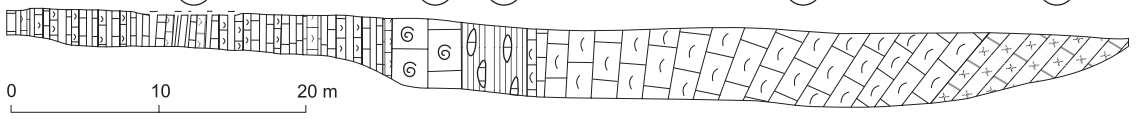

b

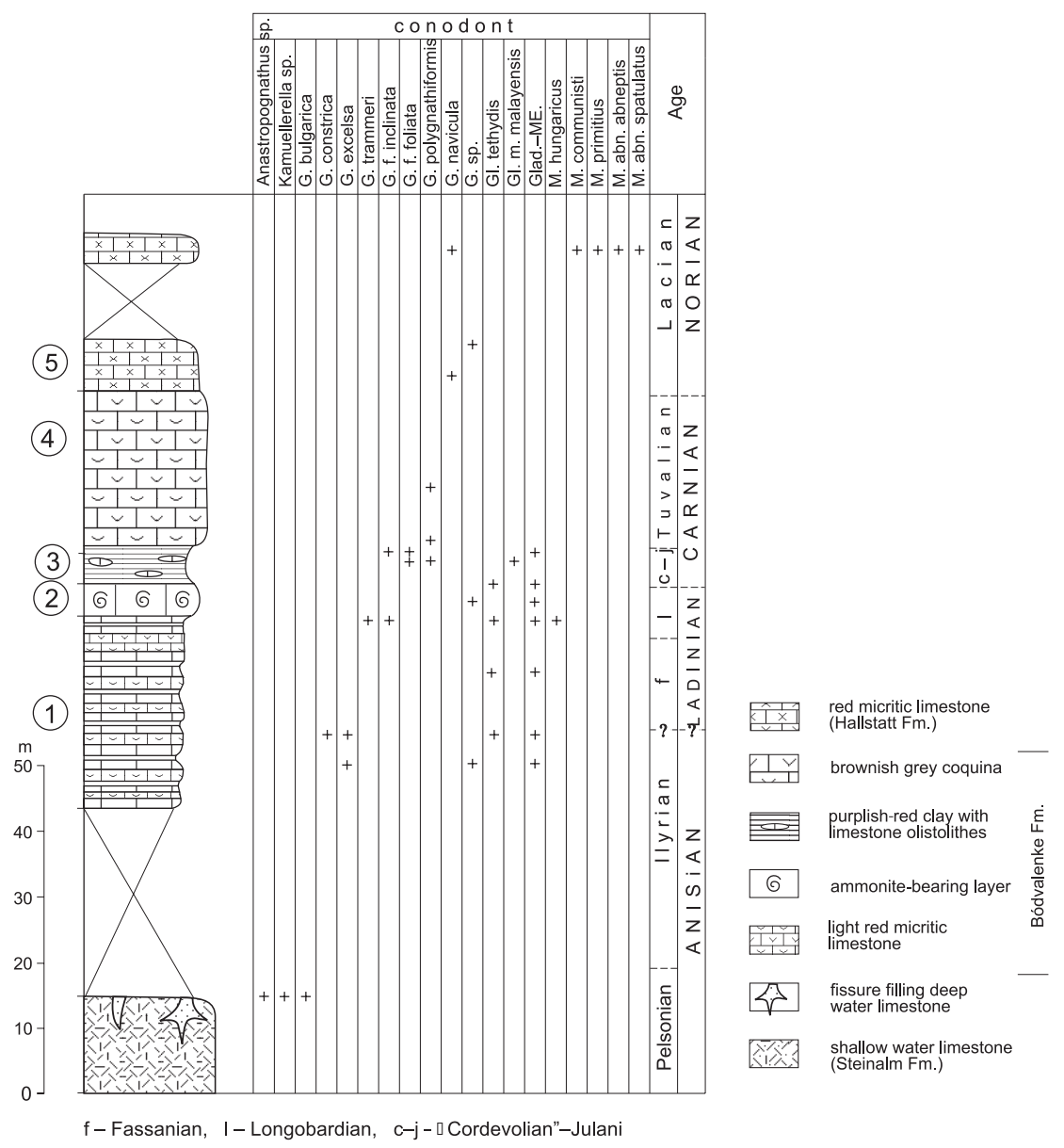

Fig. 3

a) Geologic section of the exposure (after Kovács and Less 1987). Legend: 1. Purplish-red and pink, micritic limestone, alternating with whitish gray coquina, with red chert lenses and beds. (Upper Anisian to Lower Ladinian) 2. Light red to reddish-pink, thick micritic limestone bank (5 m) (Upper Ladinian) 3. Purplish-red, partly grayish-green shale, with purplish-red micritic limestone olistoliths (Lower to Middle Carnian), 4. Light brownish gray, thick bedded coquina. (Upper Carnian.), 5. Pink and red-spotted Hallstatt Limestone (Lower Norian). b) Stratigraphic column and conodont biostratigraphy of the section (after Kovács 1986). Legend: as in Fig. 3a 


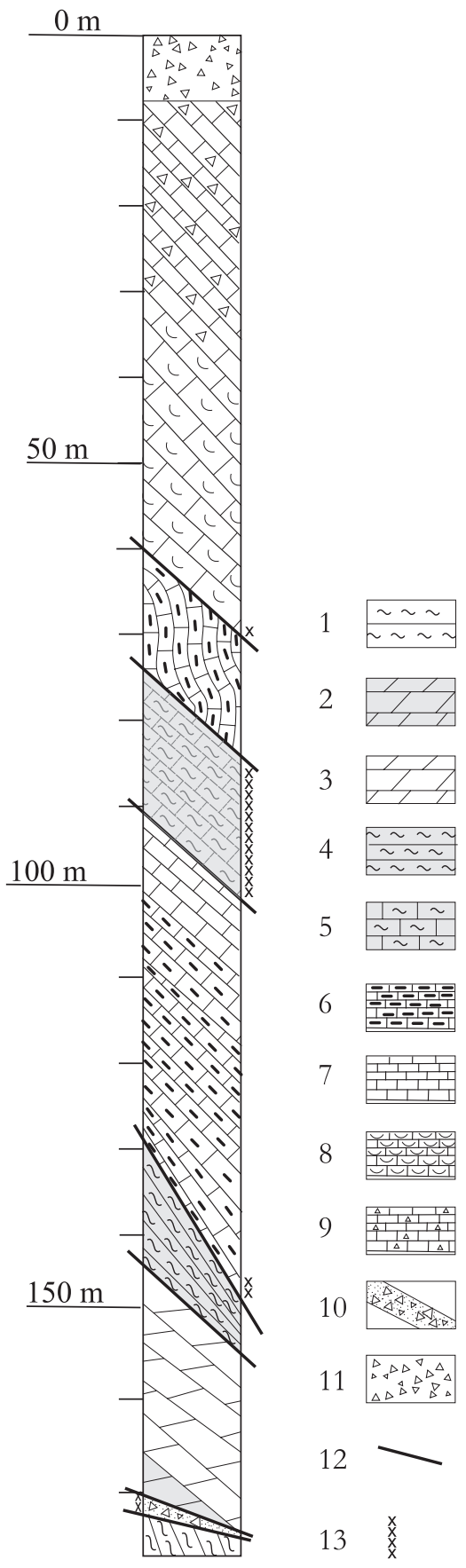

Microfacies:

- Purplish red to pink, micritic limestone beds: radiolarian "filament" biomicrite (Plate 2/1), wackestone. The micrite matrix is often recrystallised into microsparite.

- Coquina beds: "filament"-bearing pseudosparite; grainstone. The micritic limestone beds are autochthonous pelagic sediments, in which the often graded pelecypod coquina beds (Plate $2 / 2$ ) likely represent some kind of "allodapic" intercalations. The masses of Posydonia-like juvenile pelecypods probably originally lived on Sargassotype floating algae-fields. The shells accumulated on the bottom and were then redeposited via turbidity and/or bottom currents, forming either distal turbidites or contourites. The space between the thin pelecypod shells is filled with sparry calcite (pseudosparite), which formed, at least partly, by neomorphic recrystallization of the original micritic matrix.

Fig. 4

Geologic profile of borehole Bódvalenke-2. Legend: 1. Szín Marl (Upper Scythian), 2. Gutenstein Dolomite (Lower Anisian), 3. Steinalm Dolomite (Lower-Middle Anisian, with a $0.4 \mathrm{~m}$ thick Pleistocene? karstic clay filling at its top), 4. Bódvarákó Fm.: gray, siliceous marl and mudstone, rarely with dark gray chert nodules, 5. ?Bódvarákó Fm.: gray (sometimes lilac), marly limestone, with rare chert nodules (tectonically brecciated interval), 6. Bódvalenke Limestone (typical variety, with abundant red chert); 7. Bódvalenke Limestone (chert-poor variety); 8. ?Hallstatt Limestone: Posydonia coquina (Upper Carnian), 9. Hallstatt Limestone: intraformational breccia, with clasts of Massiger Hellkalk and matrix of Hangendrotkalk type (Lower Norian), 10. Tectonic breccia, 11. Quaternary debris, 12. Fault, 13. Fractured zones 

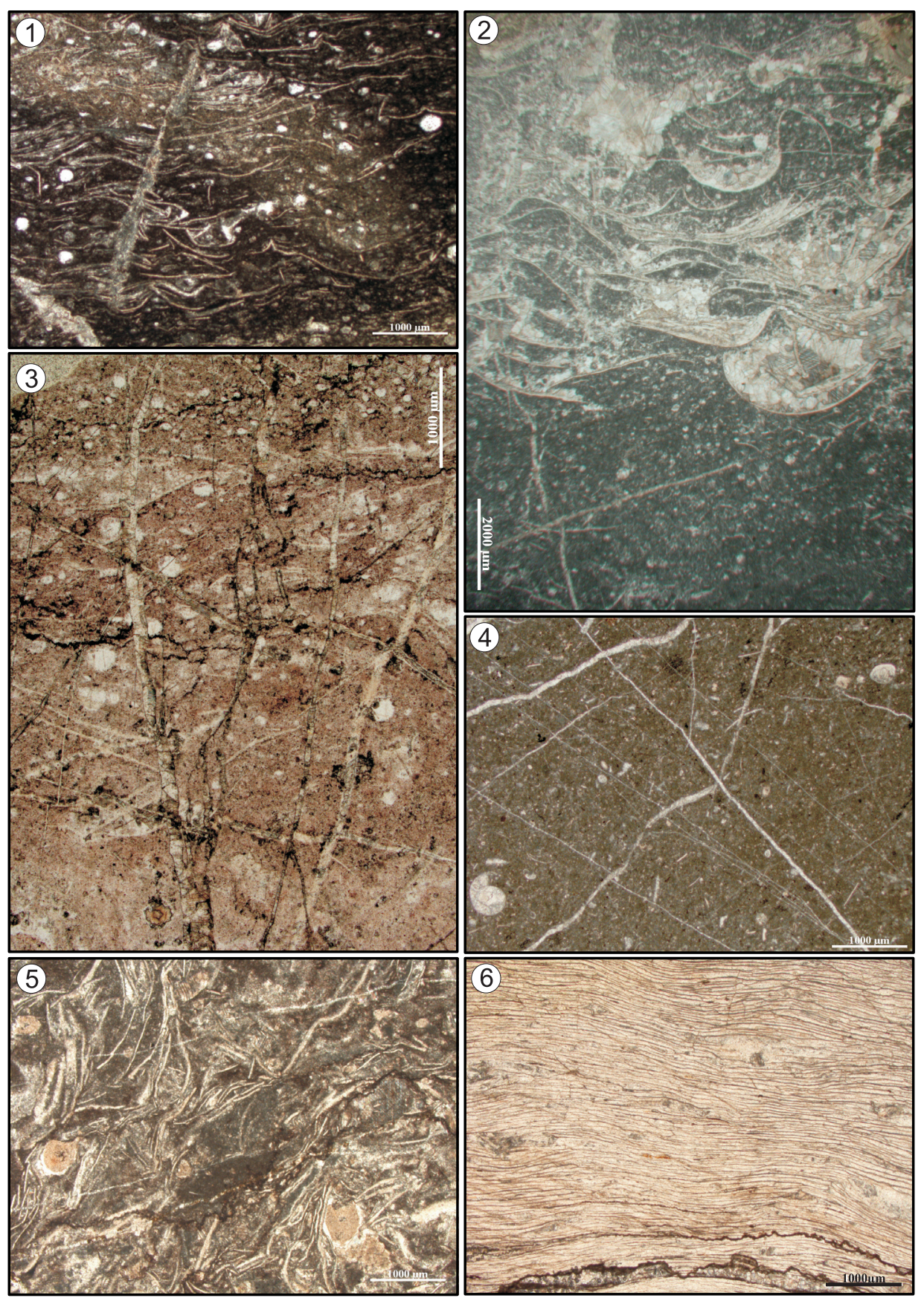

Central European Geology 53, 2010 
Age: The conodont fauna published by Kovács (1986) and re-interpreted after Kovács (1994) (samples No. 2, 3 and 4: Gondolella excelsa, G. constricta cornuta, G. constricta balkanica), taking into account that in the meantime the Anisian/ Ladinian boundary was "shifted" higher up by decision of the IUGS Triassic Subcommission (cf. Brack et al. 2005), indicates Late Anisian age. In the absence of new investigations there is no conodont biostratigraphic evidence for the base of the redefined Ladinian Stage in the section.

2. A single thick bed (5 m thick; see on Plate 1/1) of light red-reddish coloured micritic limestone with wavy internal bedding. Some poorly preserved ammonoids were formerly visible on its upper surface.

Microfacies: Radiolarian "filament"-bearing microsparitic micrite (Plate 2/3); wackestone.

Age: Only sample No. 5 taken from the base of the thick bed (Plate 1/1) yielded age-diagnostic conodont fauna: Gondolella trammeri, G. foliata inclinata, Metapolygnathus hungaricus (with transition to M. mungoensis) and M. japonicus (re-determined after Krystyn 1983). It indicates the base of the Late Ladinian (Longobardian Substage, Gredleri Zone; cf. Krystyn 1983). Higher up the poor conodont fauna does not allow identifying even the base of the Carnian, i.e. to determine whether the thick bed extends into the Carnian or not.

3. Purplish-red, partly grayish-green shale (enriched in $\mathrm{Cu}$, manifested in malachite coats), with purplish-red micritic limestone olistoliths and in its upper part with (allodapic?) intercalations. Thickness: $5 \mathrm{~m}$.

Microfacies (limestone): radiolarian "filament"-bearing micrite (Plate 2/4) and microsparitic micrite; wackestone.

Age: The conodont fauna recovered from the limestone olistoliths (samples No. 8 and 9) (Gondolella polygnathiformis, G. foliata foliata, G. foliata inclinata, Gladigondolella malayensis) indicates their Carnian age. However, the absence of the G. auriformis group (Austriacum ammonoid zone, Julian s.str.) points rather to the initial Early Carnian (Cordevolian Substage s.l. incl. the Aon and Aonoides ammonoid zones). The shale surrounding the limestone olistoliths seems evidently younger, based on analogies with the Telekes Valley sections (mainly to the Tv-VIII. section; Kovács 1991b); it can be related to the carbonate depositional minimum in late Early Carnian (Julian Substage s.str.). From the purplish red limestone beds (sample No. 10) occurring on top of the shale, just below the

$\leftarrow$ Plate 2

1. Radiolarian - "filament" wackestone

2. Radiolarian wackestone with thin-shelled bivalve coquina

3. Radiolarian wackestone (silicified)

4. Radiolarian wackestone with small fragments of thin-shelled bivalves and embryonic ammonites

5. "Filament" wackestone-packstone with a few crinoid ossicles

6. Thin-shelled bivalve coquina 
group of beds No. 4, only specimens of G. polygnathiformis were recovered, bearing evidence that this part of the formation already belongs to the lower part of the Late Carnian (Tuvalian-1/b or -2/a zones, G. polygnathiformis interval zone). These beds closing the group of beds No. 3 proves the cessation of siliciclastic input and recovery of carbonate deposition, with re-establishment of the typical Bódvalenke Limestone lithofacies for a short time.

4. Light brownish-gray, coarser crystalline, thick-bedded "filamentous" limestone (coquina), in some places with finer crystalline, pinkish admixture. This limestone forms a cliff extending from the base of the road in the direction of the Bódva River plain (Fig. 3, Plate 1/1). Thickness: approximately $30 \mathrm{~m}$.

Microfacies: "filamentous" pseudosparite; grainstone (typical pelecypod coquina) (Plate 2/5-6).

Age: From this part of the section a single specimen of the Carnian guide form Gondolella polygnathiformis was found (sample No. 11). In other sections of the Bódva Unit (Telekes Valley No. VI. and VIII.; Kovács 1991a, b) a gap occurs in this horizon, extending from Tuvalian-2/b to Lacian-1.

5. Pink and red-spotted Hallstatt Limestone with slump structures. At the western end of the section it is exposed only in approximately $5 \mathrm{~m}$ thickness, with conodont samples No. 12 and 13, but small $(<1 \mathrm{~m})$ exposures of it can be found along the road until the next curve to the $\mathrm{W}$, until about a distance of $250 \mathrm{~m}$. Dipping, as opposed to the nearly vertical up to here, becomes overturned and more and flatter.

Microfacies: radiolarian "filament"-bearing microsparitic micrite (Plate 2/6) or bioclastic microsparite; wackestone.

Age: Gondolella navicula recovered from sample No. 12, according to Krystyn (1980) already indicates the Norian age of this uppermost part of the section.

\section{Facies interpretation}

In the first group of beds (No. 1), the purplish-red to pink micritic limestone represents autochthonous pelagic sediment deposition (radiolarian-posydonia ooze). Although "filaments" (juvenile bivalve shells) may be enriched even in these beds almost as "packstone", the distinct, whitish gray-light gray, often graded coquina intercalations within these may be interpreted as redeposition into the depositional area by turbidity currents (representing distal turbidites), or by bottom currents (contourites). Red chert nodules and layers are characteristic throughout this interval; in the upper part the limestone grades almost into red chert/radiolarite.

The gradation of coquina beds in other parts of the Rudabánya Hills is more pronounced, as in the Szárhegy-East key section (Kovács 1989) and its surroundings (in the road cut in front of the entrance to the television tower). In 
the latter even the micrite is silicified (cf. Haas. ed. 2004, p. 252, Fig. 243), whereas in the key section itself the transition into radiolarite (Szárhegy Radiolarite Fm.) can be proven (although it is not red radiolarite, as opposed to the contemporaneous one in the so-called "Mn-gallery" in the Telekes Valley tributary No. VIII; cf. Haas, op. cit., p. 251). The characteristic weathering product of the formation is red chert/radiolarite detritus (Haas, op. cit., p. 253, Fig. 246), which covers large areas in the southeastern part of the Rudabánya Hills, on Dunna-tetô Hill and its surroundings (Kövér 2005).

Giving facies interpretations of the non-typical parts of the section that are not specifically of paleogeographic significance (group of beds No. 2-5) is omitted herein.

\section{Paleogeographic significance}

The typical development of the Bódvalenke Limestone in the Rudabánya Hills (as proven in several sections) was emplaced onto the disrupted and drowned Steinalm carbonate ramp, suggesting that its deposition took place on attenuated continental crust in the course of Neotethyan rifting (cf. Kovács 1997, p. 386, Fig. 6).

However, the Darnó Hill drill cores encountered a similar limestone already associated with early rift-type basalt (peperitic facies; Kiss et al. 2008) and the two formations occur in the form of slide blocks (olistothrymmata) in the Jurassic accretionary complex of the Mónosbél Unit (cf. Dosztály et al. 1998, 2002; Dimitrijević et al. 2003; Haas ed. 2004; Kovács et al. 2005, 2008). The joint occurrence of the two formations, in part proven as slide blocks, is a characteristic element of Neotethyan accretionary complexes in the Inner Dinarides - Inner Hellenides, and is characteristic mainly for the western ophiolite belt, which can be followed from the Kalnik Mts. of Croatia to the Othrys Mts., resp. Euboia Island in Greece (cf. Kovács et al. in press). Its transitional character between red pelagic micrite ("Hallstatt Limestone" s.l.) and red radiolarite is obvious and can be proven in outcrops.

The Bódvalenke key section and the Bódva Unit as a whole, being displaced along the Mid-Hungarian-Periadriatic strike-slip system, represent the northwesternmost occurrence of this transitional facies, which can be followed in the Neotethyan belt back to Oman (Baud et al. 2005). Attention to this fact was drawn by Profs. D. Bernoulli (Basel) and L. Krystyn (Vienna), both outstanding experts of the Tethyan domain, when they visited the section. Its further occurrence toward the NW is not known, either in Slovakia (Mello, pers. comm.) or in Austria (Gawlick, pers. comm.). 


\section{Acknowledgements}

Field expenses and the preparation of the present contribution were supported by National Research Fund (OTKA) grant No. K61872 of János Haas. György Less, Csaba Péró and Szilvia Kövér are thanked for their permanent help during field work. Special thanks are due to the late László Tóth, former mayor of Bódvalenke village, who several times organized the cleaning of the section as seen in Plate $1 / 1$.

\section{References}

Balogh, K. 1950: Az észak-magyarországi triász rétegtana (Triassic stratigraphy of North Hungary). Földtani Közlöny, 80, pp. 231-237.

Baud, A., S. Richoz, S. Pruss 2005: The lower Triassic anachronistic carbonate facies in space and time, International Symposium on Triassic Chronostratigraphy and Biotic Recovery, Chaohu, Anhui, China. - Albertiana, 33/1, pp. 17-19.

Brack, P., H. Rieber, A. Nicora, R. Mundil 2005: The Global Boundary Stratotype Section and Point (GSSP) for the Base of the Ladinian Stage (Middle Triassic) A proposal for the GSSP at the base of the curionii zone in the Bagolino section (Southern Alps, Northern Italy). - Episodes, 28/4, pp. 233-244.

Dimitrijević, M.N., M.D. Dimitrijević, S., Karamata, M. Sudar, N. Gerzina, S. Kovács, L. †Dosztály, Z. Gulácsi, Gy. Less, P. Pelikán 2003: Olistostrome/melanges - an overview of the problems and preliminary comparison of such formations in Yugoslavia and NE Hungary. - Slovak Geological Magazine, 9/1, pp. 3-21.

Dosztály, L., Z. Gulácsi, S. Kovács 1998: Az észak-magyarországi jura képződmények rétegtana (Stratigraphy of the Norh Hungarian Jurassic formations). - In: Bérczi, I., Á. Jámbor (Eds): Magyarország geológiai képződményeinek rétegtana (Stratigraphy of geological formations of Hungary), pp. 309-318.

Dosztály, L., S. Józsa, S. Kovács, Gy. Less, P. Pelikán, Cs. Péró 2002: North-East Hungary. Post Congress Excursion C, 1st Day Programme. - XVIIth Congress of the Carpathian-Balkan Geological Association, Guide to Geological Excursions, pp. 104-117, Bratislava.

Grill, J., S. Kovács, Gy. Less, Zs. Réti, L. Róth, I. Szentpétery 1984: Az Aggtelek-Rudabányai-hegység földtani felépítése és fejlődéstörténete (Geologischer Bau und Entwicklungsgeschichte des Aggtelek-Rudabánya Gebirges). - Földtani Kutatás, 27/4, pp. 49-56.

Haas, J. (Ed.) 2004: Magyarország geológiája - Triász (Geology of Hungary - Triassic). - ELTE Eötvös Kiadó. 384 p.

Kiss, G., F. Molnár, L.A. Palinkaš 2008: Volcanic facies and hydrothermal processes in Triassic pillow basalts from Darnó Unit, NE Hungary. - Geol. Croatica, 61, pp. 385-394.

Kovács, S. 1986: Conodonta-biosztratigráfiai és mikrofácies vizsgálatok a Rudabányai-hegység ÉK-i részén (Conodont-biostratigraphical and microfacies investigations in the Hungarian part of the northeastern part of the Rudabánya Mountains). - MÁFI Évi Jelentése 1984, p. 193-244.

Kovács, S. 1989: Aggtelek-Rudabányai-hegység, Martonyi, Szár-hegy keleti csúcsa. Szárhegyi Radiolarit Formáció (Eastern Peak of Szár-hegy, Martonyi, Aggtelek Mts. Szárhegy Radiolarite Formation). - Magyarország geológiai alapszelvényei (Key-sections of Hungary), 121, MÁFI Kiadványa, Budapest.

Kovács, S. 1991a: Rudabányai-hegység, Varbóc, Telekes-völgy, 6. sz. ÉNy-i mellékvölgy. Steinalmi, Dunnatetôi, Bódvalenkei és Hallstatti Mészkő Formációk (Rudabánya Mts, Varbóc, Telekesvölgy, Section No 6. Steinalm, Dunnatető, Bódvalenke and Hallstatt Limestone Formations). Magyarország geológiai alapszelvényei (Key-sections of Hungary) 139, MÁFI Kiadványa, Budapest. 
Kovács, S. 1991b: Rudabányai-hegység, Varbóc, Telekes-völgy, 8. sz. ÉNy-i mellékvölgy. Bódvalenkei Mészkő Formáció, Hallstatti Mészkő Formáció. (Rudabánya Mts, Varbóc, Telekes-völgy, Section No 8. Bódvalenke Limestone Formation, Hallstatt Limestone Formation). - Magyarország geológiai alapszelvényei (Key-sections of Hungary), 150, MÁFI Kiadványa, Budapest.

Kovács, S. 1994: Conodonts of stratigraphical importance from the Anisian/Ladinian boundary interval of the Balaton Highland, Hungary. - Riv. Ital. Paleont. Strat., 99/4, pp. 473-514.

Kovács, S. 1997: Middle Triassic Rifting and Facies Differentiation in Northeast Hungary. - In: Sinha, A.K., F.P. Sassi, D. Papanikolaou (Eds): Geodynamic Domains in Alpine-Himalayan Tethys, Oxford and IBH Publishing Co. Pvt. Ltd., New Delhi - Calcutta, pp. 374-397.

Kovács, S., Gy. Less, 1987: Aggtelek-Rudabányai-hegység, Bódvalenke, múút partfala, Bódvalenkei Mészkô Formáció (Aggtelek-Rudabánya Mountains, Bódvalenke, Bódvalenke Limestone Formation). - Magyarország geológiai alapszelvényei (Key-sections of Hungary), 65, MÁFI Kiadványa, Budapest.

Kovács, S., Gy. Less, O. Piros, Zs. Réti, L. Róth 1989: Triassic formations of the Aggtelek-Rudabánya Mountains. - Acta Geol. Hung., 32/1-2, pp. 31-63.

Kovács, S., S. Józsa, Z. Gulácsi, L. †Dosztály, G. B.-Árgyelán, M. Forián-Szabó, P. Ozsvárt 2005: Permo-Mesozoic Formations of the Darnó Hill Area, NE Hungary - A Displaced Fragment of the Inner Hellenidic - Inner Dinaridic accretionary Complexes. - In: Tomljenovic, B., D. Balen, I. Vlahovic (Eds): 7th Workshop on Alpine Geological Studies, Abstract Book, pp. 51-52, Zagreb.

Kovács, S., J. Haas, G. Szebényi, Z. Gulácsi, P. Pelikán, G. Bagoly-Árgyelán, S. Józsa, P. Ozsvárt, Zs. Gecse, I. Szabó 2008: Permo-Mesozoic formations of the Recsk-Darnó Hill area: stratigraphy and structure of the pre-Tertiary basement of the Paleogene Recsk Orefield. - In: Földessy, J., É. Hartai (Eds): Recsk and Lahóca geology of the Paleogene Ore Complex. - Geosciences, Miskolc University Press, pp. 33-56.

Kovács, S., J. Haas, L. A. Palinkaš, P. Ozsvárt, G. Kiss, F. Molnár, S. Józsa, Sz. Kövér 2010: Reevaluation of the Mesozoic complexes of Darnó Hill (NE Hungary) and comparisons with Neotethyan accretionary complexes of the Dinarides and Hellenides - preliminary data. Central European Geology, 53/2-3, pp. 203-232.

Kövér, Sz. 2005: Metamorf és nem-metamorf szerkezeti egységek deformációja a Rudabányaihegység középsô részén (Deformation of metamorphic and nonmetamorphic sequences in the central part of Rudabánya Hills, NE Hungary). - Szakdolgozat, ELTE Földtudományi Intézet, Budapest, $129 \mathrm{p}$.

Krystyn, L. 1980: Triassic conodont localities of the Salzkammergut Region. - Abhandlungen der Geologischen Bundesanstalt, 35, pp. 61-98.

Krystyn, L. 1983: Das Epidaurus-Profil (Griechenland) - ein Beitrag zur ConodontenStandardzonierung des tethyalen Ladin und Unterkarn. - In: Zapfe, H. (Ed.): Neue Beiträge zur Biostratigraphie der Tethys-Trias. Österr. Akad. Wiss. Schriftenr. Erdwiss. Komm., Band 5, Springer-Verlag, Wien - New York, pp. 231-258.

Less, Gy. 1981: Magyarázó az Aggtelek-Rudabányai-hegység földtani térképéhez. 1:25000-es sorozat, Hidvégardó (Explanation for geological map of the Aggtelek-Rudabánya Mts., 1:25,000). - MÁFI Adattár, manuscript.

Less, Gy. 2000: Polyphase evolution of the structure of the Aggtelek-Rudabánya Mts. (NE Hungary), the southernmost element of the Inner West Carpathians - a review. - Slovak Geological Magazine, 6/2-3, pp. 260-268. 